\title{
GIS and Remote Sensing in Industrial Development and Planning of Maunath Bhanjan City
}

\author{
Dr. Sanjay Kumar Bharati
}

Department of Geography, Institute of Science, Banaras Hindu University, Varanasi-221005, U.P., India

\begin{abstract}
Industries are not only heterogenous activities; each branch is susceptible to diverse means of organization. The interpretation of the reality of location arise from analyses that account changes in time and in technique, and that compare industrial development in the light of variations in the size of regions and nations and in their resource endowment, population and markets. The beauty of simple economic interpretation is the attraction of a model's vital statistics, the reality of her heart reminds one of the dangerous of ignoring aspects which cannot be expressed in figures [1]. The city, Maunath Bhanjan, a major handicraft and other industrial units, is an important place among urban centres of the Eastern Uttar Pradesh. The city has been an important centre of cotton textile both as manufacturing and handloom as well as power-loom in Eastern Uttar Pradesh. The surrounding region of the city has well developed as agro-based industries. This paper refers to analyse evolution, characteristics and planning of the industries of the Maunath Bhanjan city (Uttar Pradesh). This will be based on the secondary data were collected from District Industry Centre, District Statistical Handbook, Land Use Master Plan and Census data (PCA, 2011) as well as personal survey on the basis of digital map prepared by Google earth satellite imagery and application of modern tools and techniques of GIS and Remote Sensing in better planning for the industrial development of Maunath Bhanjan city.
\end{abstract}

Keywords: Characteristics and planning, Industrial development, Remote Sensing and GIS (Geographical Information System).

\section{Introduction}

The term 'Industry' describes a wide range of activity. These are as diverse as the quarrying of chalk, the smelting and refining of metals, the assembly of electronic equipment, and the ubiquitous supermarket. Industries can be classified into form groups, therefore, according to the operational process that they use: respectively, extraction, processing, assembly, and service. Each group requires specific inputs (materials, labour, capital) from specific sources for its operation and provides specific outputs for purchase in specific markets and market areas. The loctational requirements of industries in each of four the groups differ as a result; and within each group these requirements are as a 'theme with variations'. Beyond this level, the number of location variables increases rather than decreases. Industries are not only heterogenous activities; each branch is susceptible to diverse means of organization. The interpretation of the reality of location arise from analyses that account changes in time and in technique, and that compare industrial development in the light of variations in the size of regions and nations and in their resource endowment, population and markets. The beauty of simple economic interpretation is the attraction of a model's vital statistics, the reality of her heart reminds one of the dangerous of ignoring aspects which cannot be expressed in figures. Weber's analysis emphasized on location of manufacturing units and considered costs such as transport cost, labour cost and land cost due to agglomeration influencing industrial location. Von Thunen considers two significant factors transport cost and rent of land in the theory of location. Launhardt attempted an analysis of location of special manufacturing industries in terms of transport cost. Hoover's analysis is more concerned with cost than the demand factors, Palander and Ritschl also concentrated least-cost point as the optimum location August Lösch emphasised a theory of location with demand as a major spatial variable.
The intensive nature of industrial activity explains the concentration of the labour force and auxiliary services in towns, localizing there consumer and industrial markets which attract other industries and services and unleashing a process of circular and cumulative causation [2]. It should be possible, therefore, to generalize the relationships between the size, distribution, and types of industry. Alexandersson [3] and Philbrick [4] - regarding industrial scale, cities and areal functional organization in the United States - suggests itself here. Accordingly, only the three ubiquitous industries would be located in the smallest towns, while medium-sized centres would contain in addition, food manufacturing, textiles, leather and shoe and cement industries. Larger cities would be locations for steel, oil refining, chemicals, metal containers, and distilling, along with all industries of lowerrank towns. Such products as tyres, rayon, soap, cigarettes and ferm machinery appear from factories at the metropolitan level together with all lower-rank industries. The largest-scale activities are localized in the major metropolis-non-ferrous metals, motor vehicle, tractors, and pens or with typewriters in the primate city which is contains all manufacturing industries. In practice, some branches of industry are developed in particular locations, not for their accessibility to markets, but for their proximity to bulky or perishable raw materials. Agglomeration at localized sources of raw materials or nodes especially in a capitalist economy can provide exceptions to the urban industrial hierarchy [5]. Technical and economic changes have been at work, however, to reduce their importance in the industrial spectrum. Even so, they point the way to two modification of model. The first concerns the general distribution of industry. It involves the principle that manufacturing employment as a proportion of total employment varies directly with the population potential and with local urbanization, but inversely with distance from a metropolitan or major market centre [6]. Generally, as urban population densities decline with increasing distance from a central city, there is a more rapid decrease in the intensity of manufacturing and in average plant size [7]. Naturally, the 


\section{International Journal of Science and Research (IJSR) \\ ISSN (Online): 2319-7064}

Index Copernicus Value (2013): 6.14 | Impact Factor (2015): 6.391

regularity and rates of decline differ with varying regional conditions. Nevertheless, this concept seems to fit reasonably well into Isard's modification of Lösch's marketarea system [8]. However, there tends to be a concentration of large hinterland towns with specialist industries at distances of $30-65$ miles from the metropolis. This allows for the 'off - centre' location of large enterprises (e.g. steel, oil-refining, vehicles and typewriters) away from, yet near and obtaining the benefits, of the urban centre with a threshold equivalent to their market areas. This tendency is reinforced in a socialist economy by the planned spread of industry to achieve more equal regional opportunities. Closely-spaced settlements of relatively similar size and often with related specializations may form a 'dispersed city' which as a unit, contains industrial plants with market areas which equal the threshold of a single and much larger city. At greater distances from the metropolis (over 250 miles in the U.S.A.) much localized manufacturing can thrive in centres that enjoy monopolistic market condition under the protection of the prohibitive freight in cast that arise over long distances. Sharma [9], [10] examine on potentialities, location possibilities and development trends in various industries in the state of Chhattisgarh.

In the wake of growing importance of industries in the economic development of a nation or region, the localisation of industries and their proper distribution are of great significance. Here proper distribution does not mean equal distribution. Large scale industry cannot be established anywhere and everywhere. Particular industry needs some particular raw materials. It may not be possible to get all the required raw materials at one place because of improper distribution of resources. So, there arises the problem of getting all the needed commodities at a minimum cost at one place. There may be some places where the raw material can be obtained at a minimum cost. The second consideration is that manufactured goods needs vast area of demand rather than be absorbed in the local area. Therefore, the industrial unit should be located at such a place that it could meet the demand of the entire area. In general, the following factors exert considerable influence in deciding the location of industry: resources, labour, transport, and communication, site and service, market, finance and availability of entrepreneurship and talent [11], [12]. The Singh [13] worked on industrial development of Maunath Bhanjan and Mubarakpur towns in Azamgarh district (U.P.) which is focused on cotton textile, spinning, agro-based, forest based, chemical, handloom and power-loom industry and their problems and related issues. The developing infrastructural facilities and local demand also have a significant impact for future potential in the state [14]. The increasing entrepreneurship facilities and subsidies as supported by the resources, infrastructures and demand, the state has tremendous scope for economic upgradation through industrialization. The potentials for the perspective industrial development may be categorized into two broad groups: (1) resource-based, and (2) demand-based. The availability of natural resources with infrastructure facilities has attracted the diverse spread of industrial activity in different locations in the city as related to socio-economic and politico-cultural development [15]. Its manufacturing sector has yet to develop. The exploitation of various industrial raw-materials has been handicapped by lack of adequate infrastructural facilities for development. An analysis of industrial potentials is to be explored for industrial development based on local resources as well as demand-based industries of the city [16]. The city, Maunath Bhanjan, major handicrafts and other industrial units, is an important place among urban centres of the Eastern Uttar Pradesh. The city has been an important centre of cotton textile both as manufacturing and handloom as well as power-loom in Eastern Uttar Pradesh. The surrounding region of the city has well developed as agro-based industries [17], [18]. Therefore, it is imperative to evaluate the characteristics of industries and its development of Maunath Bhanjan city. Such studies become more significant in case of medium size city like Maunath Bhanjan. In the recent years, remote sensing data and geographical information system (GIS) techniques as well as Google earth satellite imagery are widely used for interpretation of map (to understand pattern), monitoring (to understand the process) and monitoring and modelling (to simulate) the planning and its development.

\subsection{Study Area}

Maunath Bhanjan City $\left(25^{0} 54^{\prime} 21^{\prime \prime} \mathrm{N}-25^{0} 59^{\prime} 08^{\prime \prime} \mathrm{N} \& 83^{0}\right.$ $30^{\prime} 16^{\prime \prime} \mathrm{E}-83^{\circ} 35^{\prime} 44^{\prime \prime} \mathrm{E}$ ) is located in the fertile alluvial land of southern (right) bank of river Tons or Tamsa or Chhoti Sarju (a tributary of river Ganga) in the heart of the triangle constituted by joining the Azamgarh, Ballia and Ghazipur district in the Eastern Uttar Pradesh (Fig.1). It lies on the main urban axis of major handicraft, industrial and commercial centres on Gorakhpur-Mau-AzamgarhShahganj-Allahabad and Varanasi-Mau-Bhatani-Gorakhpur/ Chhapra northern and north-east railways and on the crossing point of NH-29 (National Highway) and SH-34 (State Highway) roads as well as main Gorakhpur-MauVaranasi-Mumbai railway route. The city has well developed transport network and is connected with roads and railways from different part of the country (Fig.1). The city has been selected for the study on the basis of the following: (i) The city, a district headquarter (1988) and a major handicraft and other industrial units, is an important place among urban centres of Eastern Uttar Pradesh. (ii) The city has been an important centre of cotton textile both as manufacturing and handloom as well as power-loom in Eastern Uttar Pradesh. The surrounding region of the city has well developed as agro-based industries. (iii) It is typically significant to note that this city is dominated and settled by minorities (specially Muslims) consisting of about 58 percent population [23] in 2001 (2, 12, 657 persons) which reached third in the rank of the State of Uttar Pradesh after Sambhal (77\%) and Rampur (71\%). The old part of the city is highly concentrated by Muslims in the Chowk as well as south and south-west of the city. In India, its rank is $11^{\text {th }}$ as a minority city. 


\subsection{Location of Study Area}

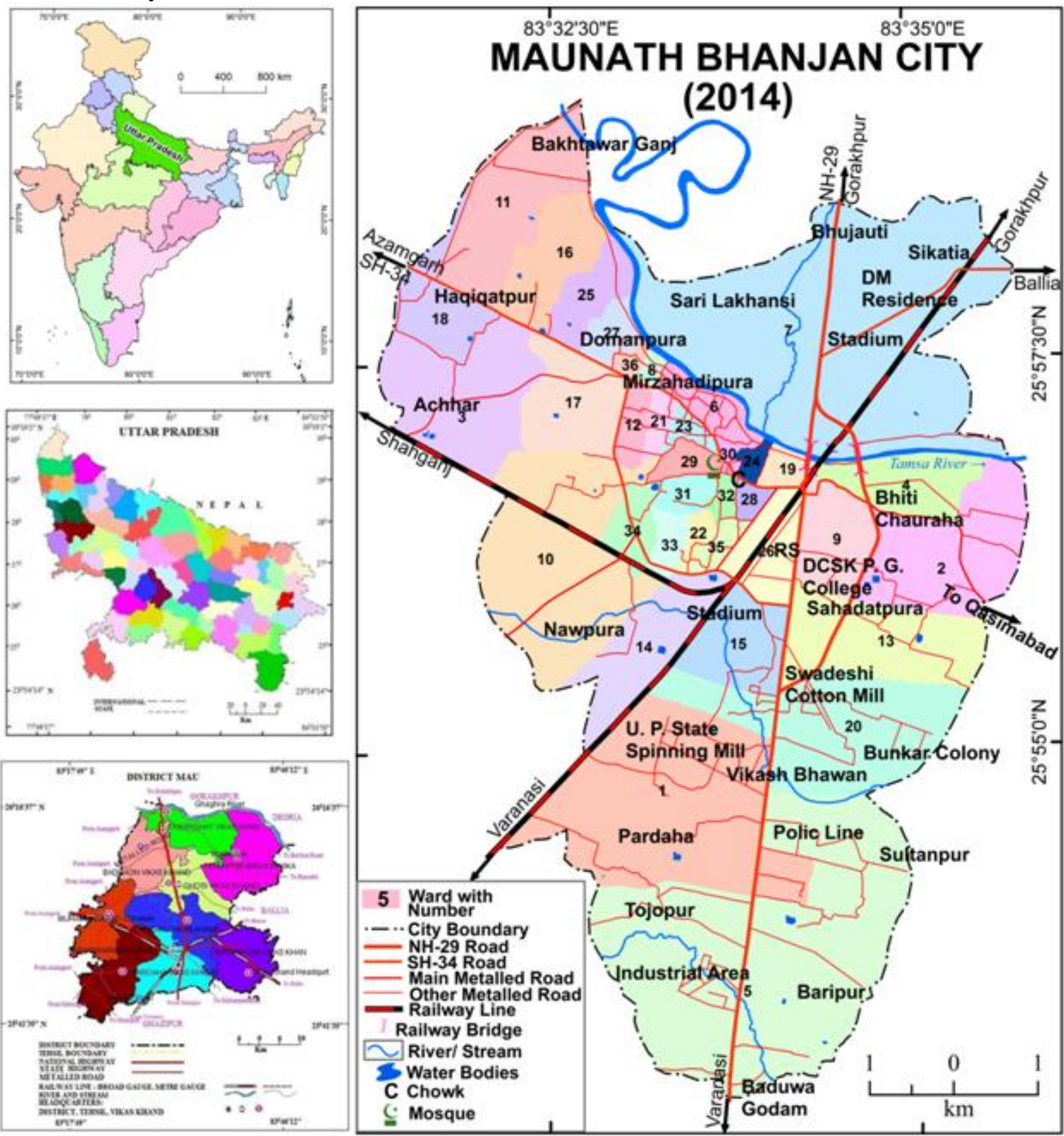

Figure 1: Location of Maunath Bhanjan City

\subsection{Objectives}

The major objectives of the study are to analyse the evolution, characteristics and planning of the different industries in Maunath Bhanjan city (Uttar Pradesh). The following aspects have been taken in to consideration:

a) To study the evolution and characteristics of the industries, and

b) To analyse the development and to proposal for a viable plan to sustain the industries of the study area.

\subsection{Data Base and Methodology}

Research is a scientific and systematic search for knowledge. It is the pursuit of truth with the help of study, observation, comparison and experiment [19]. In short, the search for knowledge through objective and systematic method of finding solution to a problem is research. In the present study, analyse the evolution, characteristics and planning of the different industries in Maunath Bhanjan city (Uttar Pradesh). The secondary data were collected through published/ unpublished records at Municipal Corporation, collected from District Industry Centre, District Statistical Handbook, Land Use Master Plan and Census data [24], PWD, Town and Country Planning Organization (TCPO) and minority town data from [23]. The primary data is generated by comprehensive field survey carried out during the year 2014-2015 to access and examine various distributions of industries. The intensive field survey was primarily conducted on the basis by mosaiced Google Earth Satellite Imageries (2014). In the field survey to draw the attention of local people regarding industries, the formal interviews with educated and aware citizens, shopkeepers

Volume 5 Issue 5, May 2016 www.ijsr.net 


\section{International Journal of Science and Research (IJSR) \\ ISSN (Online): 2319-7064}

Index Copernicus Value (2013): 6.14 | Impact Factor (2015): 6.391

and government officials were also conducted to know their views. The digitized map (Image on Arc GIS 9.3 version) was prepared with the help of Maunath Bhanjan City Town \& Village Planning Department, U.P., Azamgarh Divisional Planning Sector (Master plan - 2021, published in 2003). Google Earth Satellite imagery at 1 metre resolution was also been mosaiced on Adobe Photoshop CS4. It was geo-referenced with the help of the toposheet no. $63 \mathrm{O} / 9$. The map was digitized on Arc GIS 9.3 software and there final layout, which was done by the researcher himself. Adoption of this Technology for a country like India is very essential to assist the planners in the decision making process.

\section{Industrial Evolution of Maunath Bhanjan City}

The city has a good agricultural with reasonably moderate infra-structure of various facilities. The industrial base is strong, especially for the handicrafts and cotton textiles as it was developed with the past skilled labour and culture both. However, the main boon cotton textile, which was known for State Spining and Weaving Mill (Public Sector) was closed in 2003. The city, Maunath Bhanjan is important centre of the textiles for both power-loom as well as handloom industry. Handicrafts started in eastern Uttar Pradesh in the middle of the $16^{\text {th }}$ century. At that time Maunath bhanjan and weaving was synonym to each other. The town is identified as one of the modern weaving centre in the Eastern Uttar Pradesh. Weaving, the culture of the town, originated from this place during the period of Mughal king Jahangir around 16th century A.D. It is said that Tan Sen - one of the weavers, produced good variety of cloth at that time. Today, it has become the household industry in almost every Muslim household with a figure of around 75 thousand looms. The 'saris' of this town are unique in look and embroidery and have a large market potential in the states of Assam, Bengal, Maharastra etc. Pt. Jawahar Lal Nehru during his visits in 1957 labelled this town as "Manchester of Handloom" (Town and Village Directory, 2001). At that time Tan Sen (Julahas or weavers) setup first handicraft in the town and he made beautiful fine cloths. The town had glorious place in weaving art in Mugal period. In the Ain-i-Akbari, Maunath Bhanjan is said to be held by Sheikhs, and to be famous, along with the Jalalabad and Varanasi, among the towns of the subah of Allahabad for the manufacture of certain kinds of cotton cloth. The saris made in Maunath Bhanjan are famous at world level as special saris. The art of weaving of the town are the best, therefore, the city is also called Manchester of Handloom. At Maunath Bhanjan, weavers started manufacturing dakhhini pagri for the Marathas. Dhotis and saris for the local use as well as the southern districts were woven in large numbers. The yarn was supplied at Mau by dealers who imported it from Kanpur and Kolkata, and dyed it at home with aniline dyes for inferior articles. The finished cloth was usually sold in the open market to dealers, who had shops at Kanpur, Pune, Hyderabad and Kolkata [20].

\section{Industrial Characteristics of Maunath Bhanjan City}

Industries are the main source of economy of urban centres. Industrialisation is a significant factor for urban population growth and socio-cultural changes. Commercial, transport and other activities are growing with industries related economy. Technical knowledge and training is important for industry and, specially, household industries as in medium size industries. This city has 229.65 ha land (2014) under industrial use, i.e., 8.9 percent of the total developed land. The industrial area is demarcated about 42 ha land in which different types of industries are located. State Spinning Mill (Pardaha) and Swadesi Cotton Mill (Ghazipur road) are the significant textile units in the city. The total workers are 88, 966 persons in which 62.6 percent of total working population in the industries (Master Plan, 2021). These two mills (closed in 2003) are of textile industry and several power-loom as well as handloom units are in working condition. There is an industrial area of Uttar Pradesh State Industrial Development Committee (UPSIDC) which is 41.93 ha land on Ghazipur road. The district industry centre is 6.21 ha land for developing industrial estate in Narahi Bandh. In 2002, 93.46 ha land was under industrial use which is 6.06 percent of the total developed land. The total 98 industries (small industries) employ 290 workers in the city. The textile industry ranked first which has 32 industrial units and 101 workers. It employed 34.83 percent of total workers (Fig. 2) [21]

\subsection{Small and Small Scale Industries}

Agricultural implements, mechanical engineering goods, textile and allied products, chemicals and allied goods, plastic and rubber goods, electrical goods, glass wares, food and allied products are produced in a large number of small scale industrial units, which are mainly located in the main city.

- Agricultural implements: Ploughs, crushers, buckets, thrashers, chain pumps and pans (for making jaggery) are also produced in the city. These units are operated by electricity and use iron and coal as raw material. Mechanical engineering goods: Spare parts of machinery, rolling shutters, steel boxes, sheets, bars, pistons, couplings, flanges, liners, water pumps and nails are produced which are mainly located in the central part of the city.

- Textile and allied products: Sizing, calendering, wrapping is done in 32 units. These units manufacture cotton yarn as well. This industry is chiefly located at Chowk surrounding to Mirzahadipura. These industrial units are also engaged in job works.

- Chemicals and allied goods: Candles, Ayurvedic medicines, soap, perfumed oil and paints are manufactured in the city. These units use wax, colour, caustic soda, etc., as raw material.

- Plastic and rubber goods: Plastic badges, containers, cycle, tyres and tubes, and polethine bags are manufactured in the city. The main raw materials consumed by these units are imported, but some items are locally available. 


\section{International Journal of Science and Research (IJSR) \\ ISSN (Online): 2319-7064}

Index Copernicus Value (2013): 6.14 | Impact Factor (2015): 6.391

- Electrical goods- The manufacture of miniature bulbs and allied articles is done by 8 units, which are located in the city. These units are purchasing the entire requirement of raw material from the open market. The entrepreneurs of this industry have been advised by the industries department to start the manufacture of auto bulbs in view of the fast growing demand of the products.

- Food and allied products: Biscuits, toffee and other confectionary articles are produced in inner and middle part of the city. Sugar, maida, soojee and ghee are used as raw material in this industry. Medicated Oil: The famous Noorani Tel (oil) is manufactured by an industrial unit, Indian Chemical Company, Maunath Bhanjan, established in 1939. The oil is medicated and used to treat many ailments. The total capital of the unit is Rs. 5 lakhs and annual production varies between Rs. 27 lakhs to 39 lakhs. About 20 persons are employed in this unit. The oil is exported to Nepal also.

- Other Industries: Aluminium utensil, steel furniture, automobile parts, building materials, printing, ice-candy and bricks are produced in more than 90 units, scattered throughout the city. Most of these units employ labours on monthly or daily basis; some of them also pay wages on piece rate basis also.

- Village and Cottage industries: The village and cottage industries include mostly the handicrafts handed over from generation to generation. The persons who are engaged in these industries generally supplement their income from other sources. Handloom and power-loom cloths, leather goods, pottery, khadi weaving, woollen articles, leather tanning, gur making and blanket making fall under this group of industries, which are manned and owned by particular section of the community [20].

About 98 industries are in working condition and 290 workers are engaged in the city. Cloth industry is first rank in workers in which 101 workers are employed which is 34.83 of total workers (Table 1) [21].

Table 1: Distribution of Small and Small Scale Industries in Maunath Bhanjan City

\begin{tabular}{|c|c|c|c|c|c|}
\hline S. & \multirow{2}{*}{ No. } & Name of Industries & \multicolumn{2}{|c|}{ Industries } & \multicolumn{2}{c|}{ Workers } \\
\cline { 3 - 6 } & Numbers & Percent & Numbers & Percent \\
\hline 1 & Foods & 15 & 15.31 & 45 & 15.32 \\
\hline 2 & Cloths & 32 & 32.66 & 101 & 34.83 \\
\hline 3 & Furniture and Woods & 8 & 8.16 & 34 & 11.72 \\
\hline 4 & Chemical & 6 & 6.12 & 18 & 6.31 \\
\hline 5 & Metal and non-metal & 3 & 3.06 & 5 & 1.72 \\
\hline 6 & $\begin{array}{c}\text { Engineering and } \\
\text { Electronics }\end{array}$ & 26 & 26.53 & 67 & 23.20 \\
\hline 7 & Others & 8 & 8.16 & 20 & 6.90 \\
\hline & Total & 98 & 100.00 & 290 & 100.00 \\
\hline
\end{tabular}

Sources: District Industry Centre, Maunath Bhanjan city, 2001

\subsection{Textile Industries: Handlooms and Power-looms}

This constitutes the most important industry in the city affording maximum employment and is responsible for 60 percent of the value of industrial production in the city. Usually it is a subsidiary occupation for some 1.5 lakh of the rural population. It is a village household industry with looms set up in most of the rural households. The production process is traditional. There are about thousand power-looms in the city. The weavers are generally very proficient, possessed of innate skill, and use mill made yarn. It is first dyed in their own houses or by a local dyer. The yarn is usually obtained in the form of ranks and as such it has to be loosened and unwound before it is wrapped and sized. Unwinding, wrapping and sizing is usually done by the members of the weavers household. The dyed yarn is then operated into the pit fly shuttle loom and weaved cloth or saris or lungis are produced. The handloom and kadhi is very famous in the city. This art is still present in the environment of Mau. The Mughal king Jahangir loved this art, skill and handcrafts, since then, this art influenced the Muslim community [20]. In $16^{\text {th }}$ century, handicrafts industry started in the city and surrounding areas. Tansen, a weaver, settled first handloom in the city and made beautiful cloths. Since then, the other people learned this skill and it grew. The Mau's saris (silk as well as non-silk) are famous in the country as well as exported in the world. Pt. Nehru told that Mau is Manchester of handloom in India. Though this industry is scattered throughout the city, viz, Raghunathpura, New Masjid, Chandpura, Khiribagh, Kasimpura, Bulakipura, Pathantola, Kyaritola, Pyarepura, Aurangabad, Mirzahadipura, Jamalpura, Madanpura, Mughalpura, Hathimadari, Dakhintola, Ghas Bazaar, Alauddinpura, Emamganj, Harikishpura, etc., are main centres or famous mohallas for handloom in the city [21]. This industry has also come in the form of co-operative societies and the majority of the weavers have joined them. This industry is getting incentive from the State Government and there is a plan to change handloom into frame-cumpower-looms. With the objectives giving financial assistance, arranging raw materials at reasonable price, giving technical training, and arranging a proper market for the produced goods and intensive handloom development project has been started in Maunath Bhanjan since February, 1977. Under the control of this project about 3, 000 handlooms are engaged in producing Janta Saries at cheaper rates. About 5, 000 saries are purchased every day and are sent to different sale depots and outside the State. Besides, about ten power-looms are engaged in producing markin (plain unbleached coarse cloth) and dhotis; and about twenty handlooms are manufacturing model cloth for shirts and lungis. The bunkers make two types of cloth mainly known as Janta and non-Janta cloths. 


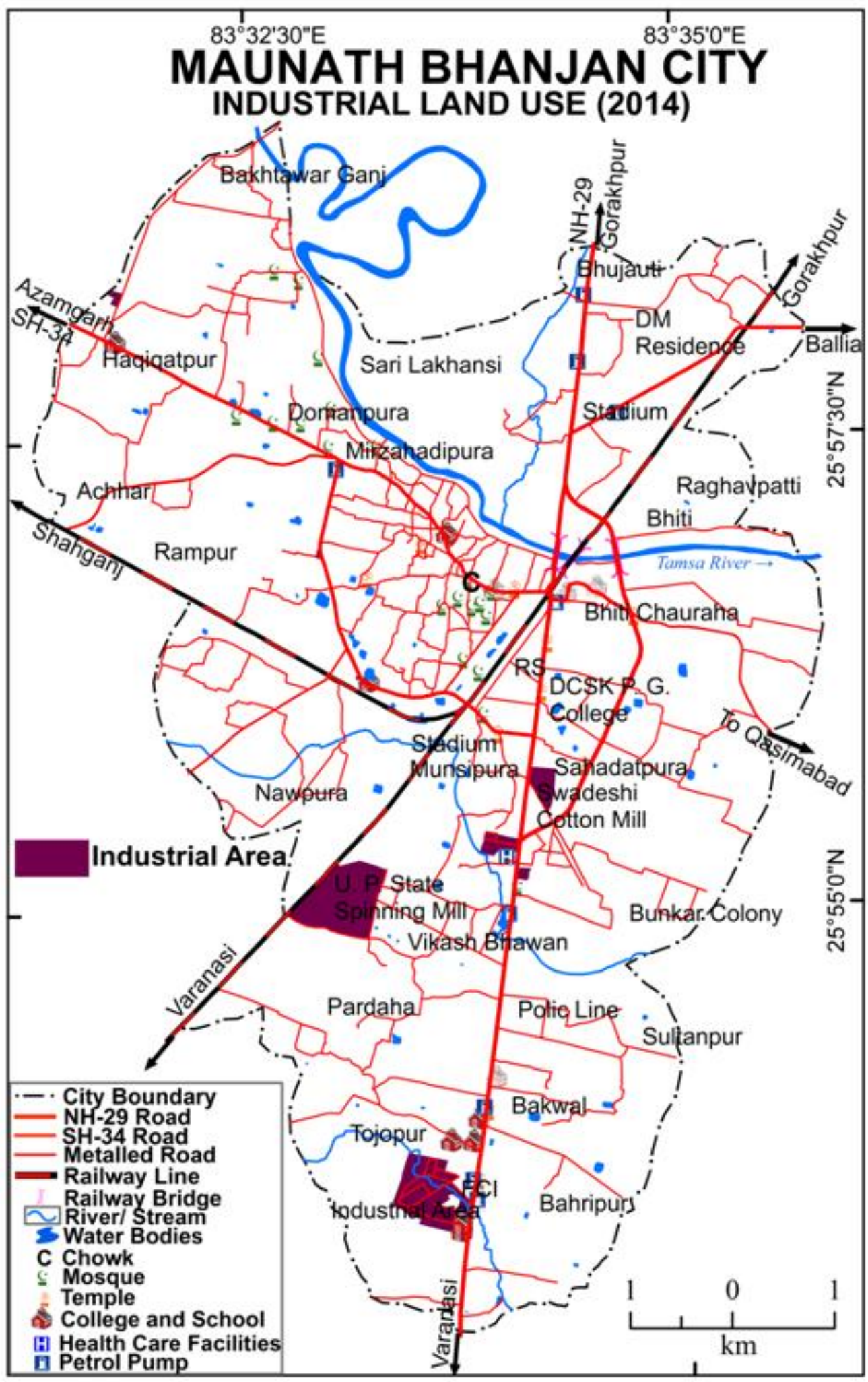

Figure 2:

Source: Map prepared by digitization of Google Earth Satellite Imagery (2014) Mosaiced Image, on Arc GIS 9.3 Software and Personal Survey.

Volume 5 Issue 5, May 2016

www.ijsr.net 
International Journal of Science and Research (IJSR)

ISSN (Online): 2319-7064

Index Copernicus Value (2013): 6.14 | Impact Factor (2015): 6.391

Maunath Bhanjan City Industrial Land Use (2014)

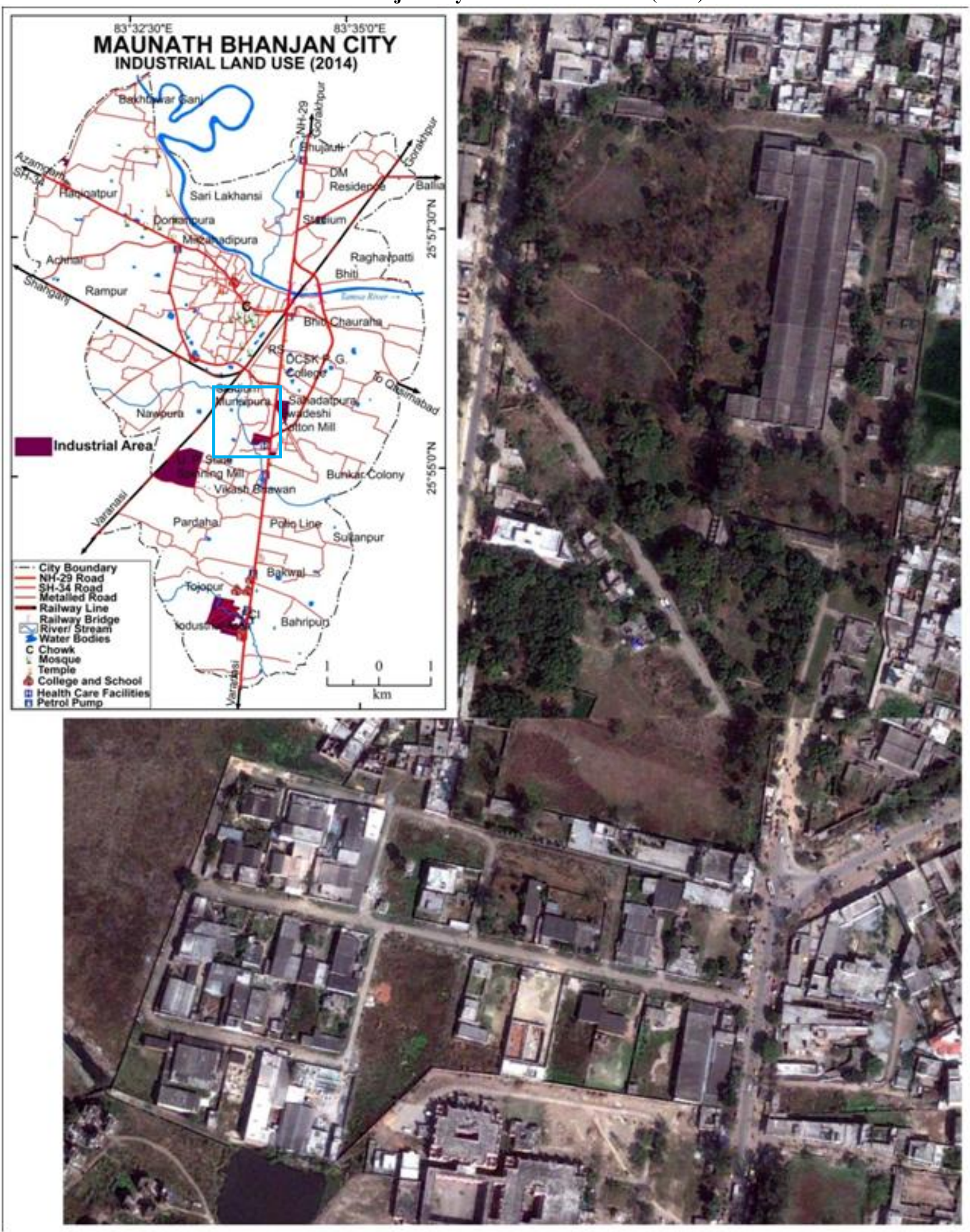

Fig. 3

Source: A. Swadesi Cotton Mill in Shahadatpura and B. Industrial Estate in Narahi Bandh, Maunath Bhanjan City. Map prepared by Google Earth Satellite Imagery (2014) Mosaiced Image, on Arc GIS 9.3 Software.

Volume 5 Issue 5, May 2016

www.ijsr.net

Licensed Under Creative Commons Attribution CC BY 


\section{International Journal of Science and Research (IJSR) \\ ISSN (Online): 2319-7064}

Index Copernicus Value (2013): 6.14 | Impact Factor (2015): 6.391

Maunath Bhanjan City Industrial Land Use (2014)
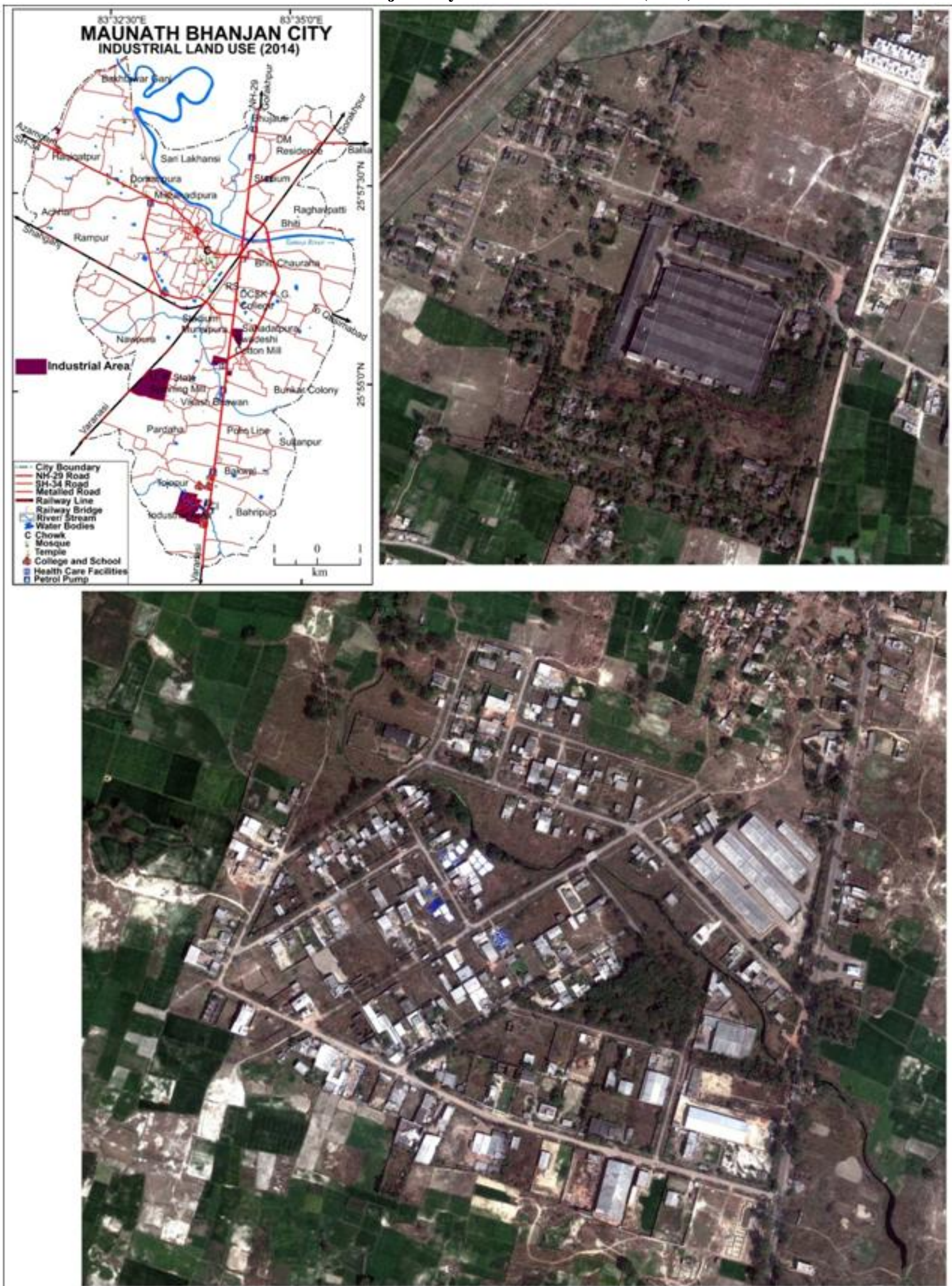

Fig. 4

Source: A. State Spinning Mill in Pardaha and B. Industrial Area in Tajopur, Maunath Bhanjan City. Map prepared by Google Earth Satellite Imagery (2014) Mosaiced Image, on Arc GIS 9.3 Software.

Janta saris and dhotis are the specific production in Mau. The textiles, silk saris, cotton saris and dhotis are of world famous in cloths market. The two textiles industry has 3203 workers, first are Swadeshi Cotton Mill governed by Central

Volume 5 Issue 5, May 2016 www.ijsr.net 


\section{International Journal of Science and Research (IJSR) \\ ISSN (Online): 2319-7064}

Index Copernicus Value (2013): 6.14 | Impact Factor (2015): 6.391

Indian Government and second is Uttar Parades State Spinning Company Limited. The area of Swadeshi Cotton Mill is 7.33 ha and 586 workers in this industry, in which 33 workers are trained and 553 workers are untrained. This mill produces mainly are cotton thread (dhaga). The area of Uttar Pradesh State Spinning Company Limited is 34.45 ha and 2617 workers in this industry, in which 865 workers are trained and 1750 workers are untrained. The cotton and synthetic yarns are made in this mill. However, these mills are closed since 2003 as sick units [21].

- Leather Goods: The manufacture of shoes and allied articles is an age old industry depending mostly on traditional skill and workmanship. The shoes made conform mostly to indigenous designs and utilize locally tanned leather. Though, this industry is scattered in middle part of the city [21].

- Pottery: One of the oldest industries of the city pottery still contributes substantially to the economic life of the people. The potters of this place still make tea cups, mugs, glass pots, sugar pots, and other decorative articles. Besides these, earthen wares and statues of gods and goddesses particularly of Ganesh, Laxmi, Shiva, Durga and Saraswati are also made as family and traditional home-hold handicrafts for festivals. These products fetch rich market during fairs and festivals.

- Leather Tanning: The city also produces leather goods and leather tanning. Artisans carry on these handicrafts on traditional and outmoded lines. The tanning materials commonly used are leaves of Amla Mathua, Bakula and Singri trees and the skins of the babul trees. This process is locality known as vegetable tanning (Herbal). The tanned hides are sold to local shoe makers [20].

- Gur Making: Next to handloom industry, gur making is the most important subsidiary industry of the rural economy. Most of the persons engaged in this industry are part-time employees, generally they are cane growers employed daily wage workers. The traditional method is still used in the processing of the gur [20].

\subsection{Industrial Estate and Industrial Area}

The established of industrial estate on Ghazipur road by the District Industrial Centre for purpose to dynamic development of the industry in Maunth Bhanjan city. This industrial estate is located on Ghazipur road (6.21 ha area), having 10 sheds and 45 blocks developed. The developed industrial estate has 41 industries and 133 workers. There is still possibility of new industries in this industrial estate in near future. There is another plan to develop industrial area on NH-29 road which is developed by Uttar Pradesh Industrial Development Corporation (41.93 ha area). This is the important plan for the industrial development in the city. There is 267 blocks for different industries. At present, 18 industries are functioning in this distributed blocks and 229 workers are engaged in these industries. The industrial base is still very strong, resulting in a high income to the city. The future industries will be developed in cloth making, forest products and agriculture-based industries (Fig. 3 \& 4) [21].

\section{Industrial Potential and Plans for Future Development}

The lack of capital and skilled human resource in the use of new technology of GIS, GPS and Remote Sensing in the developing or under developed world is making things difficult. All the software's and hardware's required by them are imported from developed countries which are less user friendly and developing world is totally dependent on developed world for any technical assistance. In the developing countries in spite of the increase in the number of growing cities and the urban population, quality of urban life is sub standard. For a good quality of life in the cities, smart planning is required. Here GIS (Geographical Information System), GPS (Global Positioning System) and RS (Remote Sensing) come handy as necessary tools and techniques in urban development planning as well as industrial development planning [22]. With the introduction of modern methods of cultivation and a minimum price guarantee for agricultural produce, the economic condition of the people has improved, providing the city a much better base for industrial development. The prospects for establishing new industries in the city are analysed on the basis of available resources and the existing and anticipated demand for various manufactured items in the city. Since there are only two small scale units in the city, there is scope for the establishment of few more and also for setting up ancillary industries. In a developing economy, means of communication play an important role because they enable a quick movement of finished goods to the markets and the raw materials to production units. Maunath Bhanjan city is in the Eastern Uttar Pradesh and lies on the Gorakhpur-MauAzamgarh-Shahganj-Allahabad and Varanasi - Mau Bhatani-Gorakhpur/Chhapra northern and north-east railways and on the crossing point of NH-29 (National Highway) and SH-34 (State Highway) roads as well as main Gorakhpur-Mau-Varanasi-Mumbai railway route. There is a network of roads, connecting this district headquarter with all the important places within and outside city.

The industries are classified under two major heads, resources based industries and demand based industries. Under the former certain industrial units can be established to utilize the available resources of the city. The city has large potential to produce agro-based industries i.e., beer brewing by barley is an important raw material, rice milling on modern lines has yet to developed which is surrounding region of the city has important paddy growing area. Sun hemp is grown in surrounding region of the city and this product can be utilized for the manufacture of rope and carpet making and an industrial unit can be easily set up in the city. At present entire quantity of this important raw material is exported to Varanasi. A potato chips plant can be established in the city due to large production of potato in surrounding region of the city. A small scale manufacturing unit for cardboard can also be established in the city, as paddy, wheat and maize, husk, the raw material of this industry is available in surrounding region of the city. A few units for fruits and vegetables preservation can also be easily established here. The city produces green peas and as people enjoys eating it in off season as well, so there is scope for the establishment of a plant for making dehydrated peas. At present flour is generally milled by atta-chakkis. With 


\section{International Journal of Science and Research (IJSR) \\ ISSN (Online): 2319-7064}

Index Copernicus Value (2013): 6.14 | Impact Factor (2015): 6.391

increasing demand for maida and soojee a roller flour mill can be open. There is a scope for opening of a few dal mills also. The major factors affecting demand for consumer goods are population (size of market), purchasing power (levels of income and disposable income), degree of urbanization, educational standards, family size, habits and outlook of consumer all of which determine the scope for demand base industries. With the advancement of modern medical aid and expression of hospitals and primary health centres, the demand for distilled saline and glucose water has increased, and some manufacturing can be easily set up to meet the demand. Besides, these units for the manufacture to agricultural implements, handpumps, cycle parts, builders hardware, steel furniture, rolling shutters, conduit pipes, electric goods, hosiery items, readymade garments, polythene sheet, plastic novelty items, soap, candle, stationery items and sports goods, can also be set up in the city. There is scope for the establishment of a few more cold storages. Cottage industries especially those with a local tradition deserve serious attention and efforts need to be made in order to revise them. There is a trade union registered in the city. The main objects of these trade union are to ensure fair wages, good living and working condition, proper medical and educational facilities for labourers and their general welfare. They also help in creating healthy relationship between the employers and the employees. There is also a labour welfare centre in the city [20].

The problems in the industrial land use are mainly in the inner and middle parts of the city. These are associated with the shortage of space for the industrial units, inconvenience of traffic jam along the roads as well as disposal of the waste products in the middle and inner parts of the city. The location of small scale and household industries particularly along Ghazipur road (NH-29) and its surrounding areas has now become suitable locations. State Spinning Mill (Pardaha) and Swadeshi Cotton Mill (Ghazipur road) are the significant textile units in the city (closed in 2003 and facing the severe problem). These industries suffer from the lack of finance and modern technology. In future, it may have detrimental impact on both people and industries. The process of shifting will definitely hamper functioning of industrial units and there will be no surprise if multitude of units gets shut down. It is leading towards unemployment. Many industrial and commercial activities are being run in the residential premises. The government has no official data available regarding this. These units rarely follow any security norm, which often leads to serious fatality of the poor labours that do not get any compensation for an accident or casualty. The industrial establishments do not reuse and recycle treated sewage to reduce fresh water demand and also contaminate the ground water. There is no authority to take any stringent action against them.

In order to meet the local requirements such service enterprises as restaurants, dhabas, DTP centres, internet cafe, photo copy centres, mobile repair shops, tent houses, nursing homes etc., have come up,

\subsection{Potentials areas for service industries}

Potentials areas for service industries are colour photo laboratories, clinic/ laboratories for pathological testing, carpentry units, automobile body building unit, hotels/restaurants, tourism centres, beauty parlour, mobile repairing, cyber café, tent house, hotel/dhaba and photo framing in the city.

\subsection{Potential for new MSMEs (Micro, Small, Medium and Enterprise)}

The potential for new Micro, Small, Medium and Enterprise in the city is fruit beverages, red brick kiln (Fixed Chimney Type), steel fabrication, leather boots \& shoes, engineering workshop, modern rice mill, ground spices, mineral water, agarbati sticks manufacturing, agricultural implements, bakery items, plastic products, poultry feed, dal (pulse) mills, packaging material, roller flour mills, jam, jellies \& pickles, dairy farm, power-loom Industry, chemical industries, general engineering, food product industry.

\section{Conclusion}

The industry of Maunarh Bhanjan city exhibits the imprints of physical environment as well as historical aspects dealing with endogenetic as well as exogenetic forces. Maunath Bhanjan city is an important centre of trade and commerce as well as industrial hub which is reflected in the urban structure. The city has a good agricultural with reasonably moderate infra-structure of various facilities. The industrial base is strong, specially for the handicrafts and cotton textiles as it was developed with the past skilled labour and culture both. However, the main boon cotton textile, which was known for State Spining and Weaving Mill (Public Sector) was closed in 2003. The city, Maunath Bhanjan is important centre of the textiles for both power-loom as well as handloom industry. Handicrafts started in Eastern Uttar Pradesh in the middle of the $16^{\text {th }}$ century. At that time Maunath bhanjan and weaving was synonym to each other. The town is identified as one of the modern weaving centre in the Eastern Uttar Pradesh. Weaving, the culture of the town, originated from this place during the period of Mughal king Jahangir around 16th century A.D. Today, it has become the household industry in almost every Muslim household with a figure of around 75 thousand looms. The 'saris' of this town are unique in look and embroidery and have a large market potential in the states of Assam, Bengal, Maharastra etc. Pt. Jawahar Lal Nehru during his visits in 1957 labelled this town as "Manchester of Handloom" (Town and Village Directory, 2001). At that time Tan Sen (Julahas or weavers) setup first handicraft in the town and he made beautiful fine cloths. The industry distribution and density has spread in three clusters: (i) first around the Mirzahadipur Tiraha in the west and Chowk (Old settlement area) in the core (central part of the city) which has developed (Handloom and power-loom) along old Azamgarh-Ballia State Highway-34, (ii) second near Ghazipur Tiraha which has developed (industrial estate and Swadeshi Cotton Mill) in along Ghazipur road National Highway-29 and, (iii) third along Ghazipur road National Highway-29 which has developed Industrial Area in outer periphery of the city near Tojopur. The city has small scale and medium/large scale industries as well as one industrial estate and one industrial area in the well demarcated area on the Ghazipur road (NH-29). At present, the two industrial units are State Spinning Mill (Pardaha) and Swadeshi Cotton 


\section{International Journal of Science and Research (IJSR) \\ ISSN (Online): 2319-7064}

Index Copernicus Value (2013): 6.14 | Impact Factor (2015): 6.391

Mill (Shahadatpura) is the significant textile units in the city (closed in 2003) and protected by walled boundary. Dhotis and saris for the local use as well as the southern districts were woven in large numbers. The yarn was supplied at Mau by dealers who imported it from Kanpur and Kolkata, and dyed it at home with aniline dyes for inferior articles. The finished cloth was usually sold in the open market to dealers, who had shops at Kanpur, Pune, Hyderabad and Kolkata.

\section{Acknowledgement}

The author is grateful to University Grant Commission (CSIR-UGC-Senior Research Fellowship) to conduct research and also to Prof. P. R. Sharma (Retd.) in Banaras Hindu University.

\section{References}

[1] Hamilton, F.E.I., (ed.), (1968). Models of Industries, Ebenezer Baylis \& Son, Ltd., The Trinity Press, Worcester and London, pp. 361-417.

[2] Myrdal, G., (1957). Economic Theory and Underdeveloped Countries, (Londan), p. 168.

[3] Alexandersson, G., (1956). The Industrial Structure of American cities, Lincoln, Nebraska), p. 134.

[4] Philbrick, A. K., (1957). Principles of Areal Functional organisation in Regional Human Geography, Economic Geography, Vol. 33, pp. 299-336.

[5] Hagget, P., (1965). Locational Analysis in Human Geography, (Londan), p. 339.

[6] Duncan, B., (1959). Population Distribution and Manufacturing Activity; The Non - Metropolitan United States in 1950 Papers and Proceedings, Regional Science Association, 5, pp. 95-103.

[7] Bogue, D. J., (1949). The Structure of the Metropolitan Community: A Study of Dominance and Subdominance; (Ann Arbov), p. 210.

[8] Isard, W., (1956). Location and Space Economy, New York), p. 350.

[9] Sharma, P. R., (1973). An Appraisal of Mineral Resources and Prospects for Industrial Establishments in Chhattisgarh Region. The Indian Geographical Journal, XLVIII: pp. 24-37.

[10] Sharma, P. R., (1980). Industries of Chhattisgarh. Geographical Review of India, 42 (2): pp. 146-157.

[11] Singh, M. B., (1979). Industrial Development Pattern and Potentials in Eastern U.P.: A Geographical Analysis, Ph.D. Thesis, B.H.U., Varanasi.

[12] Singh, M. B., (1983). Industrial Development Pattern and Potentials in Eastern U.P., Lotus Publication, Varanasi.

[13] Singh, J. P., (1989). Industrial Development of Maunath Bhanjan and Mubarakpur Tehsil, Dist. Azamgarh, Ph.D. thesis, BHU, Varanasi.

[14] Sharma, V. N., (1987). An Appraisal of Industrial Development and Potentials in Madhya Pradesh, Ph.D. Thesis, B.H.U., Varanasi.

[15] Mishra, N. K., (2012). Industry of Chhattisgarh: Location Facters, Development and Planning, Verlag: LAP LAMBERT Academic Publishing GmbH \& Co.KG, Germany.
[16] Mishra, N. K., (2014). Industrial Potential in Chattisgarh, National Geographical Journal of India, Vol. 60, Pt. 4, December, pp. 423-430.

[17] Bharati, S. K., Sharma, P. R., 2010, Maunath Bhanjan Nagar ka Udbhav avam Vikash, Rastirrya Bhaugolic Patrika, (NGJI), Vol. 1\& 2, pp. 5-18.

[18] Bharati, S. K., Sharma, P. R., (2014). Maunath Bhanjan City: An Appraisal of Urban Land Use, Change and Characteristics, National Geographical Journal of India, Vol. 60, Pt. 1, March, pp. 27-40.

[19] Sharma, P. R., et. al. (ed.), (2011). Research Methodology Concept and Studies, RK BOOKS 4215/, Ansari Road, Daryaganj, New Delhi, p.3.

[20] Singh, Balwant, (1989). Uttar Pradesh District Gazetteer, Azamgarh, published by Government of Uttar Pradesh, State Editor, pp. 2-278.

[21] Sharma, S.C., (2003). Maunath Bhanjan city, Master Plan Proposal - 2021, Town and Village Planning Department, U.P., Azamgarh Divisional Planning Sector.

[22] Tiwary, A. N., (2016). GIS and Remote Sensing in Urban Development Planning: Issues and Challenges of Developing World, International Journal of Science and Research (IJSR), ISSN (Online): 2319-7064, Vol.5, Issue-4, April, 2016, pp. 86-90.

[23] UIDSSMT, (2010). Urban Infrastructure Development Scheme for Small and Medium Towns, Ministry of Urban Development, Government of India, http://www.uidssmt.org; Accessed on 26.02.2014.

[24] Census of India, (2011). Town Directory. Directorate of Census Operations, Uttar Pradesh, Lucknow. 